\title{
The Randall B. Griepp Honorary Paper
}

\author{
Steven Lansman, MD, PhD
}

Dr Griepp was the founding director of the Aortic Symposium (Figure 1). By way of recognizing his contributions to the symposium and the field of thoracic aortic surgery, The American Association of Thoracic Surgery is instituting the policy of distinguishing the best abstract submitted to the Aortic Symposium as "The Randall B. Griepp Honorary Paper."

Dr Griepp received a Bachelor of Science degree from the California Institute of Technology and a Medical Doctor degree from Stanford University Medical School. He went on to complete a medical internship at Bellevue Hospital in New York City, where he met his wife, Eva Botstein Griepp, a pediatric cardiologist, who collaborated on much of the laboratory and clinical work throughout Dr Griepp's career and who edited all of the abstracts and manuscripts for the Aortic Symposium series.

Dr Griepp returned to Stanford in July of 1968, where he completed general surgical and cardiac surgical training under Dr Norman E. Shumway. These were exciting times in cardiac surgery and at Stanford in particular, as Dr Shumway had performed his first heart transplant, the world's forth, on January 6, 1968. Dr Griepp performed his first heart transplant on January 1, 1970, and for many years that patient was the longest heart transplant survivor, surviving 26 years. Along with Dr Edward B. Stinson, Dr Griepp led the Stanford heart transplant team during the early 1970s, the formative years of cardiac transplantation, when only several institutions worldwide were actively developing cardiac transplant programs. During this period, Dr Griepp was first author of a number of key publications that helped establish heart transplantation as a viable, reliable clinical option; he also participated with Dr Peer Portner on the development of mechanical assist devices.

Drs Shumway and Griepp shared a research interest in the application of hypothermia to cardiac surgery. In 1973, Drs Griepp, Stinson, and Shumway described the protective effect of topical hypothermia for protection of the human heart during cardiac surgery. ${ }^{1}$ In 1975 , using surface cooling and cardiopulmonary bypass to induce

\footnotetext{
From the Department of Surgery, Westchester Medical Center, Valhalla, NY. Disclosures: Author has nothing to disclose with regard to commercial support. Read at The American Association for Thoracic Surgery Aortic Symposium, New York, New York, April 24-25, 2014.

Received for publication Oct 10, 2014; accepted for publication Oct 18, 2014; available ahead of print Dec 13, 2014

Address for reprints: Steven Lansman, MD, PhD, Department of Surgery, Westchester Medical Center, Macy Pavilion 114W, Valhalla, NY 10595 (E-mail: lansmans@ wcmc.com).

J Thorac Cardiovasc Surg 2015;149:S1-2

$0022-5223 / \$ 36.00$

Copyright (c) 2015 by The American Association for Thoracic Surgery

http://dx.doi.org/10.1016/j.jtcvs.2014.10.086
}

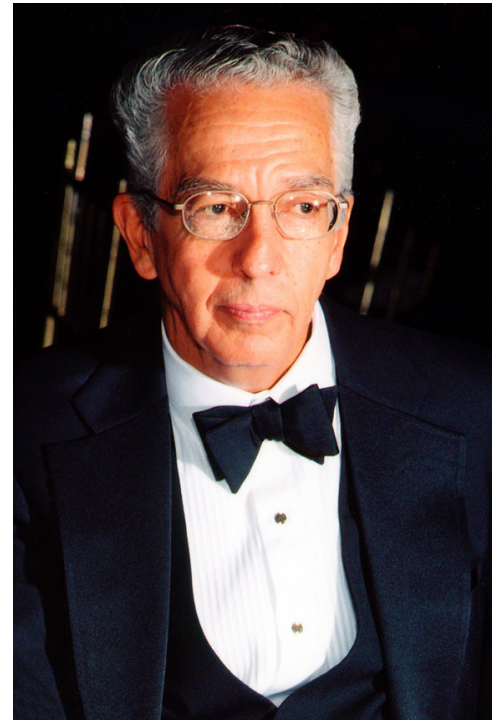

FIGURE 1. Randall B. Griepp, MD.

hypothermia, Dr Griepp published a technique for total arch replacement using deep hypothermic circulatory arrest at $12^{\circ} \mathrm{C}$ to $18^{\circ} \mathrm{C}$, which reduced cerebral metabolic demand to tolerable levels and provided a bloodless operative field in which to work. ${ }^{2}$ The approach became the standard for more than 2 decades.

Having been an attending cardiac surgeon on Dr Shumway's service for several years, in 1976 Dr Griepp simultaneously completed a chief residency in General Surgery and then was recruited to become Chief of Cardiothoracic Surgery at the State University of New York, Brooklyn. Shortly after moving to New York, with the untimely illness of Dr Samuel L. Kountz, Dr Griepp became Chairman of Surgery for the State University Hospital and Kings County Hospital. During this period, Dr Griepp teamed up with Dr M. Arisan Ergin. They continued the work on arch replacement using deep hypothermia, ${ }^{3}$ and the partnership proved enormously productive over the coming 25 years in terms of clinical and academic output, particularly in the field of aortic surgery.

In 1985, Dr Griepp became Professor and Chairman of the Department of Cardiothoracic Surgery at Mount Sinai Hospital in New York City, where he built a world-renowned program and developed a busy clinical practice in pediatric cardiac surgery and aortic surgery. Dr Griepp's curriculum vitae is extensive, but a number of his many contributions to aortic surgery can be categorized into 5 broad areas: natural history of thoracic aortic aneurysms, ${ }^{4,5}$ hypothermic circulatory arrest, ${ }^{6-9}$ safe parameters for selective cerebral perfusion, ${ }^{10,11}$ arch 
replacement using a trifurcated graft, ${ }^{12}$ and spinal cord protection, including elaboration of the spinal collateral network model.

Dr Griepp trained 32 chief residents and many fellows in cardiothoracic surgery, 13 of whom became Chairman or Chiefs of Service at their respective institutions. He served as director of the Aortic Symposium series from 1988 to 2012.

\section{References}

1. Griepp RB, Stinson EB, Shumway NE. Profound local hypothermia for myocardial protection during open-heart surgery. J Thorac Cardiovasc Surg. 1973;66:731-41.

2. Griepp RB, Stinson EB, Hollingsworth JF, Buehler D. Prosthetic replacement of the aortic arch. J Thorac Cardiovasc Surg. 1975;70:1051-63.

3. Ergin MA, O'Connor J, Guinto R, Griepp RB. Experience with profound hypothermia and circulatory arrest in the treatment of aneurysms of the aortic arch. Aortic arch replacement for acute arch dissections. J Thorac Cardiovasc Surg. 1982;84:649-55.

4. Juvonen T, Ergin MA, Galla JD, Lansman SL, Nguyen KH, McCullough JN, et al. Prospective study of the natural history of thoracic aortic aneurysms. Ann Thorac Surg. 1997;63:1533-44.

5. Juvonen T, Ergin MA, Galla JD, Lansman SL, McCullough JN, Nguyen K, et al. Risk factors for rupture of chronic type B dissections. J Thorac Cardiovasc Surg. 1999;117:776-86.

6. Ergin MA, Uysal S, Reich DL, Apaydin A, Lansman SL, McCullough JN, et al. Temporary neurological dysfunction after deep hypothermic circulatory arrest: a clinical marker of long-term functional deficit. Ann Thorac Surg. 1999;67: 1887-90.

7. McCullough JN, Zhang N, Reich DL, Juvonen TS, Klein JJ, Spielvogel D, et al. Cerebral metabolic suppression during hypothermic circulatory arrest in humans. Ann Thorac Surg. 1999;67:1895-9.

8. Ehrlich MP, Hagl C, McCullough JN, Zhang N, Shiang H, Bodian C, et al. Retrograde cerebral perfusion provides negligible flow through brain capillaries in the pig. J Thorac Cardiovasc Surg. 2001;122:331-8.

9. Griepp RB, Di Luozzo G. Hypothermia for aortic surgery. J Thorac Cardiovasc Surg. 2013;145:S56-8.

10. Halstead JC, Meier M, Wurm M, Zhang N, Spielvogel D, Weisz D, et al. Optimizing selective cerebral perfusion: deleterious effects of high perfusion pressures. J Thorac Cardiovasc Surg. 2008;135:784-91.

11. Etz CD, Luehr M, Kari FA, Lin HM, Kleinman G, Zoli S, et al. Selective cerebral perfusion at 28 degrees C-is the spinal cord safe? Eur J Cardiothorac Surg. 2009; 36:946-55

12. Spielvogel D, Strauch JT, Minanov OP, Lansman SL, Griepp RB. Aortic arch replacement using a trifurcated graft and selective cerebral antegrade perfusion. Ann Thorac Surg. 2002;74:S1810-4.

13. Griepp RB, Ergin MA, Galla JD, Lansman S, Khan N, Quintana C, et al. Looking for the artery of Adamkiewicz: a quest to minimize paraplegia after operations for aneurysms of the descending thoracic and thoracoabdominal aorta. J Thorac Cardiovasc Surg. 1996;112:1202-15.

14. Galla JD, Ergin MA, Sadeghi AM, Lansman SL, Danto J, Griepp RB. A new technique using somatosensory evoked potential guidance during descending and thoracoabdominal aortic repairs. J Card Surg. 1994;9: 662-72.

15. Griepp RB, Griepp EB. Spinal cord perfusion and protection during descending thoracic and thoracoabdominal aortic surgery: the collateral network concept. Ann Thorac Surg. 2007;83:S865-9. 